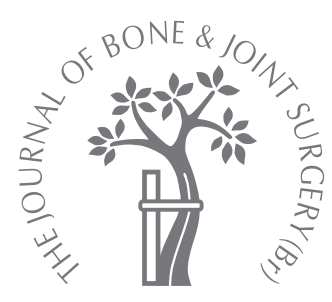

\title{
Radiological evidence of femoroacetabular impingement in mild slipped capital femoral epiphysis
}

\author{
A MEAN FOLLOW-UP OF 14.4 YEARS AFTER PINNING IN SITU
}

C. R. Fraitzl,
W. Käfer,
M. Nelitz,
H. Reichel

From the University of Ulm, Ulm, Germany

\footnotetext{
E. R. Fraitzl, MD,

Orthopaedic Surgeon

W. Käfer, MD, Attending

Orthopaedic Surgeon

M. Nelitz, MD, Attending

Orthopaedic Surgeon

H. Reichel, MD, Professor and Head of Department

Department of Orthopaedics University of Ulm, Oberer

Eselsberg 45, D-89081 UIm,

Germany
}

Correspondence should be sent to $\operatorname{Dr}$ C. R. Fraitzl; e-mail: christian.fraitzl@uni-ulm.de

(C2007 British Editorial Society of Bone and Joint Surgery

doi:10.1302/0301-620X.89B12. $19637 \$ 2.00$

$J$ Bone Joint Surg $[\mathrm{Br}]$

2007;89-B:1592-6.

Received 3 May 2007; Accepted after revision 6 August 2007

\begin{abstract}
Conventional treatment of mild slipped capital femoral epiphysis consists of fixation in situ with wires or screws. Recent contributions to the literature suggest that even a mild slip may lead to early damage of the acetabular labrum and adjacent cartilage by abutment of a prominent femoral metaphysis. It has been suggested that the appropriate treatment in mild slipped capital femoral epiphysis should not only prevent further slipping of the epiphysis, but also address potential femoroacetabular impingement by restoring the anatomy of the proximal femur.

Between October 1984 and December 1995 we treated 16 patients for unilateral mild slipped capital femoral epiphysis by fixation in situ with Kirschner wires. In this study we have reviewed these patients for clinical and radiological evidence of femoroacetabular impingement. There was little clinical indication of impingement but radiological evaluation assessing the femoral head-neck ratio and measuring the Nötzli $\alpha$ angle on the anteroposterior and cross-table radiographs showed significant alterations in the proximal femur. None of the affected hips had a normal head-neck ratio and the mean $\alpha$ angle was $86^{\circ}\left(55^{\circ}\right.$ to $\left.99^{\circ}\right)$ and $55^{\circ}\left(40^{\circ}\right.$ to $\left.94^{\circ}\right)$ on the anteroposterior and lateral cross-table radiographs, respectively.

While our clinical data favours conventional treatment, our radiological findings are in support of restoring the anatomy of the proximal femur to avoid or delay the development of femoroacetabular impingement following mild slipped capital femoral epiphysis.
\end{abstract}

Clinically symptomatic or silent slipping of the capital femoral epiphysis is one mechanism that leads to the development of cam-type femoroacetabular impingement and subsequent osteoarthritis (OA) of the hip. ${ }^{1-9}$ The treatment of slipped capital femoral epiphysis (SCFE) is usually surgical and depends on the severity of the slip, generally defined by the angulation of the femoral epiphysis relative to the axis of the femoral neck. For mild slips, with angulation $<30^{\circ}$, fixation of the epiphysis in situ by smooth pins or screws is recommended in the literature as well as in the German national guidelines. ${ }^{10-14}$ Two reports, with a mean follow-up of 31 and 41 years respectively, showed good long-term results for pinning in situ, not only in mild but also in moderate and severe slips. ${ }^{10,12}$

However, two recent publications have suggested that soon after slipping of the epiphysis, changes occur at the acetabular labrum and adjacent cartilage which are precursors of OA of the affected hip joint. ${ }^{3,5}$ In these two studies, after arthrotomy and surgical dislocation as described by Ganz et al, ${ }^{15}$ intra-articular eval- uation of the hip joints revealed erosions, scars and/or tears of the labrum, with damage to the articular cartilage ranging from superficial abrasions to full-thickness loss caused by a prominent femoral metaphysis protruding beyond, or at least level with, the epiphysis. These findings led the authors to recommend that in mild SCFE, in addition to stabilisation of the epiphysis in situ an osteochondroplasty at the femoral head-neck junction should be performed in an attempt to reduce the risk of developing secondary osteoarthritis. ${ }^{3,5}$ If this advice was followed in mild SCFE a small procedure would be replaced by an invasive operation, with the potential risk of producing avascular necrosis of the femoral head. However, surgical dislocation of hips with SCFE has been reported ${ }^{16-19}$ as part of treatment in a limited number of patients. No severe adverse effects were reported, or in the patients described by Leunig et al. ${ }^{3,5}$

In an attempt to substantiate this newlyproposed therapeutic approach to the deformity resulting from mild SCFE, and as femoroacetabular impingement typically becomes symptom- 
Table I. Activity levels according to the score of Tegner and Lysholm ${ }^{24}$

\begin{tabular}{|c|c|}
\hline Level & Description \\
\hline 0 & Sick leave or disability pension \\
\hline 1 & $\begin{array}{l}\text { Work: sedentary } \\
\text { Walking on even ground possible }\end{array}$ \\
\hline 2 & $\begin{array}{l}\text { Work: light labour } \\
\text { Walking on uneven ground possible but impossible to walk } \\
\text { in forest }\end{array}$ \\
\hline 3 & $\begin{array}{l}\text { Work: light labour (eg. nursing) } \\
\text { Competitive and recreational sports: swimming } \\
\text { Walking in forest possible }\end{array}$ \\
\hline 4 & $\begin{array}{l}\text { Work: moderately heavy labour (eg. truck driving, heavy } \\
\text { domestic work) } \\
\text { Recreational sports: cycling, cross-country skiing, jogging } \\
\text { on even ground at least twice weekly }\end{array}$ \\
\hline 5 & $\begin{array}{l}\text { Work: heavy labour (eg. building, forestry) } \\
\text { Competitive sports: cycling, cross-country skiing } \\
\text { Recreational sports: jogging on uneven ground at least } \\
\text { twice weekly }\end{array}$ \\
\hline 6 & $\begin{array}{l}\text { Recreational sports: tennis and badminton, handball, bas- } \\
\text { ketball, downhill skiing, jogging (at least five times per } \\
\text { week) }\end{array}$ \\
\hline 7 & $\begin{array}{l}\text { Competitive sports: tennis, athletics (running), motorcross/ } \\
\text { speedway, handball, basketball } \\
\text { Recreational sports: soccer, bandy and ice hockey, squash, } \\
\text { athletics (jumping) } \\
\text { Cross-country track findings both recreational and competi- } \\
\text { tive }\end{array}$ \\
\hline 8 & $\begin{array}{l}\text { Competitive sports: bandy, squash or badminton, athletics } \\
\text { (jumping etc), downhill skiing }\end{array}$ \\
\hline 9 & $\begin{array}{l}\text { Competitive sports: soccer (lower divisions), ice hockey, } \\
\text { wrestling, gymnastics }\end{array}$ \\
\hline 10 & Competitive sports: soccer (national and international elite) \\
\hline
\end{tabular}

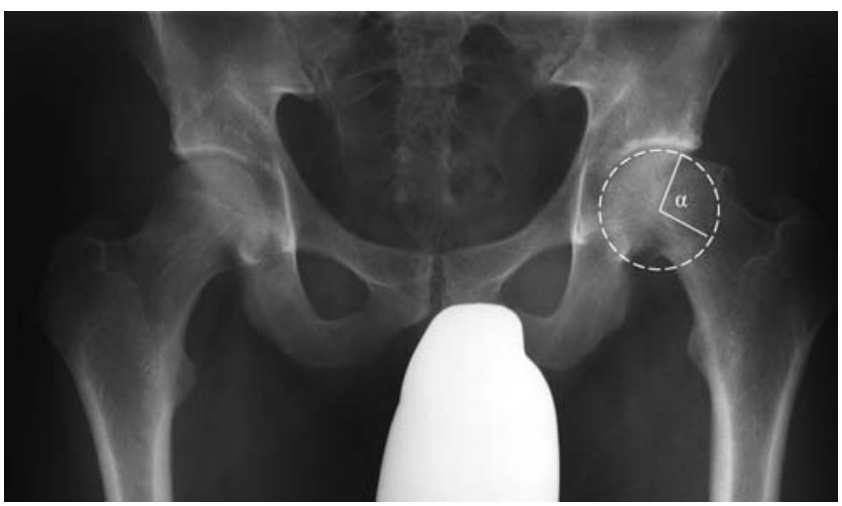

Fig. 1

Anteroposterior pelvic radiograph of a 28-year-old man, approximately 12 years after in situ pinning of both proximal femora. The unaffected right hip shows a normal head-neck junction; the affected left hip has a markedly reduced head-neck ratio and a bony prominence at the headneck junction. Angle $\alpha$ is defined according to Nötzli et $\mathrm{al}^{26}$ by a line connecting the centre of the femoral head with the centre of the femoral neck and a line connecting the centre of the femoral head with a point on the head-neck contour where the latter leaves a circle projected over the femoral head. The $\alpha$ angle is $99^{\circ}$.

using K-wires. A total of 16 patients could be contacted and evaluated.

Before evaluation, the documented angles of slip were remeasured on the lateral Lauenstein radiographs ${ }^{22}$ taken at first presentation. The extent of the slip was determined by measuring the angle between the base of the slipped epiphysis and a line perpendicular to the axis of the femoral neck. ${ }^{23}$

The occupation and sports activities of the patients according to the activity score of Tegner and Lysholm ${ }^{24}$ were recorded (Table I). Clinical examination included recording the range of movement of both hips and the impingement provocation test, ${ }^{25}$ where pain in the groin is potentially provoked by internal rotation and adduction in $90^{\circ}$ flexion, when lesions of the acetabular labrum are present.

Radiological evaluation was performed using anteroposterior (AP) radiographs of the pelvis and lateral cross-table views of both hips. The head-neck ratio of the proximal femur was described qualitatively for both planes by assigning it to one of four groups: normal ratio, mildly reduced ratio, reduced ratio or marked reduction/completely lacking. A reduced ratio was assumed when a reduction of the headneck ratio by approximately half of the normal ratio was present. A mildly reduced and markedly reduced ratio was assumed when a reduction was less than, and more than half the standard ratio, respectively. In addition, the presence of a bony prominence at the head-neck junction was noted. To quantitatively describe differences of the head-neck contour, the $\alpha$ angle, as described previously, ${ }^{26,27}$ was determined in both planes (Fig. 1). All clinical and radiological evaluations were undertaken by the senior author (CRF).

Statistical analysis was performed using SPSS 11.0.2 software (SPSS Inc., Chicago, Illinois). Statistical signifi- 
Table II. Range of movement and ventral impingement provocation test in the affected and unaffected hips of the 16 patients

\begin{tabular}{|c|c|c|c|c|}
\hline & Affected & Unaffected & p-value & Test \\
\hline Mean flexion ( ${ }^{\circ}$ ) (range) & 112 (90 to 130$)$ & 113 (90 to 135$)$ & 0.43 & Paired $t$-test \\
\hline Mean internal rotation $\left({ }^{\circ}\right)$ (range) & $16(5$ to 30$)$ & 23 (10 to 35$)$ & $<0.01$ & $\begin{array}{l}\text { Wilcoxon's matched-pairs } \\
\text { signed-ranks test }\end{array}$ \\
\hline Mean abduction $\left({ }^{\circ}\right)$ (range) & 38 (25 to 55$)$ & 42 (30 to 55$)$ & 0.02 & $\begin{array}{l}\text { Wilcoxon's matched-pairs } \\
\text { signed-ranks test }\end{array}$ \\
\hline $\begin{array}{l}\text { Impingement provocation test } \\
\text { (number of hips) }\end{array}$ & 6 & 5 & 1.0 & Fisher's exact test \\
\hline
\end{tabular}

Table III. Qualitative radiological findings and radiological presence of bony prominence at the head-neck junction in the affected and unaffected hips of the 16 patients

\begin{tabular}{lllll}
\hline & Affected & Unaffected & p-value & Test \\
\hline $\begin{array}{l}\text { Distinctly reduced or absent } \\
\text { head-neck ratio }\end{array}$ & 10 & 4 & & \\
$\begin{array}{l}\text { Reduced ratio } \\
\text { Mildly reduced ratio }\end{array}$ & 2 & 1 & $<0.02$ & $\begin{array}{l}\text { Chi-squared test for } \\
\text { independence }\end{array}$ \\
$\begin{array}{l}\text { Normal ratio } \\
\text { Bony prominence }\end{array}$ & 0 & 4 & & Fisher's exact test \\
\hline
\end{tabular}

Table IV. Measurement of $\alpha$ angle of Nötzli et $\mathrm{al}^{26}$

\begin{tabular}{cllll}
\hline Mean angle $\left(^{\circ}\right)$ (range) & Affected & Unaffected & p-value & Test \\
\hline on anteroposterior radiograph & $86(55$ to 99$)$ & 62 (45 to 90$)$ & $<0.01$ & $\begin{array}{l}\text { Wilcoxon's matched-pairs } \\
\text { signed-ranks test } \\
\text { on cross-table radiograph }\end{array}$ \\
\hline $55(40$ to 94$)$ & $46(33$ to 68$)$ & 0.03 & $\begin{array}{l}\text { Wilcoxon's matched-pairs } \\
\text { signed-ranks test }\end{array}$ \\
\hline
\end{tabular}

cance was examined using the Wilcoxon's matched-pairs signed-ranks test, Fisher's exact test or the chi-squared test for independence, according to the characteristics of the investigated data. The level of significance was set at $\mathrm{p}<0.05$.

\section{Results}

All 16 patients were Caucasian. There were 13 males and three females. In 12 males and two females, the left hip was affected and in one male and one female, the right hip was affected. The mean age of the patients on admission was 13.6 years (11.8 to 17.1$)$ and the mean period of follow-up was for 14.4 years (11.3 to 21.2 ). The mean angle of slip was $17^{\circ}$ $\left(12^{\circ}\right.$ to $\left.31^{\circ}\right)$. The normal side was not measured. The femoral epiphysis had been pinned on the affected side with three Kwires in four hips, with four in eight, five in three, and six in one, and on the unaffected side with three K-wires in five hips, four in ten and five in one. There was no statistically significant difference in the number of wires applied between the affected and unaffected sides (Wilcoxon's matched-pairs signed-ranks test, $\mathrm{p}=0.063$ ). All the pins had been placed through a lateral skin incision distal to the greater trochanter and after the fascia lata had been split over a small distance.
When grading activity according to Tegner and Lysholm, ${ }^{24}$ one patient had an activity level of 3, eight a level of 4 , five a level of 6 and two a level of 9 . These latter two both played competitive football but had sedentary occupations. Clinical examination revealed mean flexion of $112^{\circ}$ $\left(90^{\circ}\right.$ to $\left.130^{\circ}\right)$ in the affected and $113^{\circ}\left(90^{\circ}\right.$ to $\left.135^{\circ}\right)$ in the unaffected hip, internal rotation was a mean of $16^{\circ}\left(5^{\circ}\right.$ to $\left.30^{\circ}\right)$ in the affected and $23^{\circ}\left(10^{\circ}\right.$ to $\left.35^{\circ}\right)$ in the unaffected hip, and the mean abduction was $38^{\circ}\left(25^{\circ}\right.$ to $\left.55^{\circ}\right)$ in the affected and $42^{\circ}\left(30^{\circ}\right.$ to $\left.55^{\circ}\right)$ in the unaffected hip. Statistically significant differences were found for internal rotation (Wilcoxon's matched-pairs signed-rank test, $\mathrm{p}<0.01$ ) and abduction (Wilcoxon's matched-pairs signed-rank test, $\mathrm{p}=0.02$ ), but not for flexion (paired $t$-test, $\mathrm{p}=0.43$ ) between the affected and the unaffected hips. The impingement provocation test was found to be positive in six affected and five unaffected hips, which was not statistically significant (Fisher's exact test, $\mathrm{p}=1.0$ ) (Table II).

Radiological evaluation of the head-neck ratio revealed an absent or distinctly reduced ratio in ten affected hips and four unaffected hips, a reduced ratio in two affected hips and one unaffected hip, a mildly reduced ratio in four from each group and a normal ratio in none of the affected hips 
and seven of the unaffected hips. A statistically significant difference was found between the affected and the unaffected hips (chi-squared test for independence, $p<0.02$ ). Significantly more bony prominences at the head-neck junction were found in the affected hips than in the unaffected hips (Fisher's exact test, $\mathrm{p}<0.03$ ) (Table III).

Measurement of the $\alpha$ angle revealed a statistically significant difference between the affected and unaffected hips. It was a mean of $86^{\circ}\left(55^{\circ}\right.$ to $\left.99^{\circ}\right)$ and $62^{\circ}\left(45^{\circ}\right.$ to $\left.90^{\circ}\right)$ (Wilcoxon's matched-pairs signed-ranks test, p < 0.01), respectively, on AP radiographs and $55^{\circ}\left(40^{\circ}\right.$ to $\left.94^{\circ}\right)$ and $46^{\circ}$ $\left(33^{\circ}\right.$ to $68^{\circ}$ ) (Wilcoxon's matched-pairs signed-ranks test, $\mathrm{p}=0.03$ ), respectively on cross-table radiographs (Table IV). In both planes the majority of the deformity of the head-neck contour occurred laterally.

\section{Discussion}

Only recently has femoroacetabular impingement been described as one possible mechanism for developing OA of the hip joint. ${ }^{4,6,7,9,15,17-19,28-30}$ Structural abnormalities of the acetabular rim and/or the anterolateral head-neck junction of the proximal femur may lead to either pincer-type impingement, a cam-type impingement, or a combination of both. For cam-type femoroacetabular impingement the underlying conditions are not yet clarified. Besides a growth abnormality of the capital femoral epiphysis, ${ }^{31}$ subclinical and clinical SCFE are discussed as one possible cause for a reduced or absent head-neck ratio. ${ }^{1-9}$ Many studies consider different diagnostic or therapeutic options in SCFE in the short and long term, ${ }^{10,12,13,32,33}$ but do not describe the midterm, when femoroacetabular impingement typically evolves. Follow-up of between seven and 16 years is documented in a few studies from the 1950 s to the 1980 s, prior to the recognition of femoracetabular impingement. ${ }^{11,34-36}$ We have studied patients who suffered from SCFE in their adolescence and are now at the age when symptoms of impingement are typically manifest.

Although originally developed for the evaluation of patients with knee ligament injuries, the Tegner and Lysholm activity score ${ }^{24}$ revealed that more than half of our patients, with a mean age of 28.1 years at follow-up, did not exceed level 4, suggesting that the functional outcome precluded more athletic pursuits.

When looking at the range of movement, flexion, internal rotation and abduction are predominantly restricted by the metaphysis becoming prominent through posterior and medial displacement of the epiphysis. ${ }^{2}$ There was a significant reduction of internal rotation and abduction, but not of flexion, which would be expected to occur in femoroacetabular impingement. Additionally, the extent of the internal rotation, although restricted compared with the normal hip, was more than the maximum of $10^{\circ}$ typically assumed for femoroacetabular impingement. ${ }^{6}$ However, it must be acknowledged that there is no linear relationship between the loss of internal rotation and the extent of the damage caused by impingement after SCFE, because in mild slips the prominence of the metaphysis may still enter the joint and abraid the acetabular cartilage, in contrast to moderate or severe slips, where a larger metaphyseal prominence may be obstructed from entering the joint by the acetabular rim.

The ventral impingement provocation test, ${ }^{25}$ although not specific, is positive in the vast majority of patients with symptomatic femoroacetabular impingement, ${ }^{6,18}$ but in our group it was positive in less than half the affected hips. Furthermore, it was positive in five unaffected hips, which may suggest a systemic growth disturbance in SCFE, leading to bilaterality. ${ }^{13,33,37,38}$

The radiographs demonstrated considerable changes in the head-neck ratio, with no affected hips, and only seven of the unaffected hips having a normal ratio. Bony prominences at the head-neck junction were found in 13 of the affected but only six of the unaffected hips.

The normal $\alpha$ angle is considered to be $42^{\circ} .^{26}$ The mean $\alpha$ angle on the AP radiographs was $86^{\circ}$ in the affected and $62^{\circ}$ in the unaffected side. Although this constituted a significant difference between the affected and unaffected hips, both values clearly differ from the norm, showing that although prophylactically pinned, the unaffected side did not develop normally. This may be as a result of a systemic disturbance of development of the growth plate in affected individuals, as suggested by the frequent bilateral presentation, ${ }^{13,33,37,38}$ or a disturbance induced by the operative procedure itself.

From the cross-table radiographs, the mean $\alpha$ angle was $55^{\circ}$ for the affected and $46^{\circ}$ for the unaffected side, which was a statistically significant difference, but differed less from the normal value of $42^{\circ}$, especially for the unaffected side. Remodelling of the head-neck junction has been proposed by Bellemans et $\mathrm{al}^{39}$ as one important process leading to good long-term results observed after in situ pinning in SCFE and obviously takes place at a favourable site, anteriorly. This may explain why the majority of our patients, although following less physically demanding life-styles perform well for 10 to 20 years after in situ pinning of the SCFE.

In conclusion, there were few clinical signs of femoroacetabular impingement 10 to 20 years after in situ pinning. However, radiological evaluation supports the proposition that proximal femoral osteochondroplasty might avoid or delay the development of femoroacetabular impingement after mild SCFE.

No benefits in any form have been received or will be received from a commercial party related directly or indirectly to the subject of this article.

\section{References}

1. Goodman DA, Feighan JE, Smith AD, et al. Subclinical slipped capital femoral epiphysis. J Bone Joint Surg [Am] 1997;79-A:1489-97.

2. Rab GT. The geometry of the slipped capital femoral epiphysis: implications for movement, impingement, and corrective osteotomy. J Pediatr Orthop 1999;19:419-24.

3. Leunig M, Casillas MM, Hamlet $\mathbf{M}$, et al. Slipped capital femoral epiphysis: early mechanical damage to the acetabular cartilage by a prominent femoral metaphysis. Acta Orthop Scand 2000;71:370-5.

4. Ito M, Minka M-A 2nd, Werlen S, Ganz R. Femoroacetabular impingement and the cam-effect: a MRI-based quantitative anatomical study of the femoral head-neck offset. J Bone Joint Surg [Br]2001;83-B:171-6. 
5. Leunig M, FraitzI CR, Ganz R. Early damage to the acetabular cartilage in slipped capital femoral epiphysis: therapeutic consequences. Orthopade 2002;31:894-9 (in German).

6. Ganz R, Parvizi J, Beck M, et al. Femoroacetabular impingement: a cause for osteoarthritis of the hip. Clin Orthop 2003;417:112-20.

7. Ito K, Leunig M, Ganz R. Histopathologic features of the acetabular labrum in femoroacetabular impingement. Clin Orthop 2004;429:262-71.

8. Beck M, Kalhor M, Leunig M, Ganz R. Hip morphology influences the pattern of damage to the acetabular cartilage: femoroacetabular impingement as a cause of early osteoarthritis of the hip. J Bone Joint Surg [Br]2005;87-B:1012-18.

9. Leunig M, Beck M, Dora C, Ganz R. Femoroacetabular impingement: trigger for the development of coxarthrosis. Orthopade 2006;36:77-84 (in German).

10. Boyer DW, Mickelson MR, Ponseti IV. Slipped capital femoral epiphysis: long-term follow-up study of one hundred and twenty-one patients. J Bone Joint Surg [Am] 1981;63-A:85-95

11. Kulick RG, Denton JR. A retrospective study of 125 cases of slipped capital femora epiphysis. Clin Orthop 1982;162:87-90.

12. Carney BT, Weinstein SL, Noble J. Long-term follow-up of slipped femoral epiphysis. J Bone Joint Surg [Am] 1991;73-A:667-73.

13. Seller K, Wild AT, Westhoff B, Raab P, Krauspe R. Radiological evaluation of unstable (acute) slipped capital femoral epiphysis treated by pinning with Kirschner wires. $J$ Pediatr Orthop B 2006;15:328-34.

14. No authors listed. Present guidelines. Register number 33. Epiphyseolysis capitis femoris. http://leitlinien.net (date last accessed 26 July 2007)

15. Ganz R, Gill TJ, Gautier E, et al. Surgical dislocation of the adult hip. J Bone Joint Surg [Br] 2001;83-B:1119-24.

16. Jager M, Wild AT, Westhoff B, Krauspe R. Femoroacetabular impingement caused by a femoral osseous head-neck deformity: clinical, radiological, and experimental results. J Orthop Sci 2004;9:256-63.

17. Murphy SB, Tannast M, Kim Y-J, Buly RL, Millis MB. Debridement of the adult hip for femoracetabular impingement: indications and preliminary results. Clin Orthop 2004;429:178-81.

18. Peters CL, Erickson JA. Treatment of femoro-acetabular impingement with surgica dislocation and debridement in young adults. J Bone Joint Surg [Am] 2006;88-A:173541.

19. Spencer S, Millis MB, Kim Y-J. Early results of treatment for hip impingement syndrome in slipped capital femoral epiphysis and pistol grip deformity of the femoral headneck junction using the surgical dislocation technique. J Pediatr Orthop 2006;26:281-5.

20. Leunig M, Ganz R. Femoroacetabular impingement: a common cause of hip complaints leading to arthrosis. Unfallchirurg 2005;108:9-17 (in German).

21. Wettstein $\mathbf{M}$, Dienst $\mathbf{M}$. Hip arthroscopy for femoroacetabular impingement. Orthopade 2006;35:85-93 (in German).
22. Tönnis D. Allgemeine Röntgendiagnostic des Hüftgelenks. In: Tönnis D, ed. Die angeborene Hüftdysplasie und Hüfluxation im kindes - und Erwachsenenatter. Berlin: Springer-Verlag,1984.

23. Debrunner HU, Hepp WR. Orthopadisches diagnostikum. Sixth ed. Stuttgart: Georg Thieme Verlag, 1994:162-7.

24. Tegner Y, Lysholm J. Rating systems in the evaluation of knee ligament injuries. Clin Orthop 1985;198:43-9.

25. MacDonald SJ, Garbuz D, Ganz R. Clinical evaluation of the symptomatic young adult hip. Seminars in Arthroplasty 1997;8:3-9.

26. Notzli HP, Wyss TF, Stoecklin CH, et al. The contour of the femoral head-neck junction as a predictor for the risk of anterior impingement. J Bone Joint Surg $[\mathrm{Br}]$ 2002;84-B:556-60.

27. Meyer DC, Beck M, Ellis T, Ganz R, Leunig M. Comparison of six radiographic projections to assess femoral head/neck asphericity. Clin Orthop 2006;445:181-5.

28. Beck M, Leunig M, Parvizi J, et al. Anterior femoroacetabular impingement. Part II: midterm results of surgical treatment. Clin Orthop 2004;418:67-73.

29. Espinosa N, Rothenfluh DA, Beck M, Ganz R, Leunig M. Treatment of femoroacetabular impingement: preliminary results of labral refixation. J Bone Joint Surg [Am] 2006;88-A:925-35.

30. Crawford JR, Villar RN. Current concepts in the management of femoroacetabular impingement. J Bone Joint Surg [Br] 2005;87-B:1459-62.

31. Siebenrock KA, Wahab KHA, Werlen S, et al. Abnormal extension of the femoral head epiphysis as a cause of cam impingement. Clin Orthop 2004;418:54-60.

32. Kallio PE, Paterson DC, Foster BK, Lequesne GW. Classification in slipped capital femoral epiphysis: sonographic assessment of stability and remodelling. Clin Orthop 1993;294:196-203.

33. Jerre R, Billing L, Hansson G, Wallin J. The contralateral hip in patients primarily treated for unilateral slipped upper femoral epiphysis: long-term follow-up of 61 hips. J Bone Joint Surg [Br] 1994;76-B:563-7.

34. Howorth B. Slipping of the upper femoral epiphysis. Clin Orthop 1957;10:148-73.

35. Howorth B. Slipping of the capital femoral epiphysis: treatment. Clin Orthop 1966;48:53-70.

36. Wilson PD, Jacobs B, Schecter L. Slipped capital femoral epiphysis: an end-result study. J Bone Joint Surg [Am] 1965;47-A:1128-45.

37. Loder RT, Aronson DD, Greenfield ML. The epidemiology of bilateral slipped capital femoral epiphysis: a study of children in Michigan. J Bone Joint Surg [Am] 1993;75-A:1141-7.

38. Bhatia NN, Pipiris M, Otsuka NY. Body mass index in patients with slipped capital femoral epiphysis. J Pediatr Orthop 2006;26:197-9.

39. Bellemans J, Fabry G, Molenaers G, Lammens J, Moens P. Slipped capital femoral epiphysis: a long-term follow-up with special emphasis for remodeling. J Pediatr Orthop B 1996:5:151-7. 